\title{
BLACK MIRROR: DESTROYING THE IDYLL OF HAPPY CHILDHOOD, OR THE SOCIUM TODAY IN THE MILLENIALS' POETRY
}

\author{
S. Danilova \\ Philology, History and Culture of the USA, St. Petersburg University \\ Universitetskaya, 7-9, St. Petersburg, Russia, 199034
}

This essay is a look into the black mirror of lost - or inversed - myths. It's about the society of disconnected people; about new generation of creative persons - the Millenials - who are trying to find their own place in the world by different ways, and the major of them is Poetry.

Stefania Danilova is the youngest member of Writers' Union of Russia. She is polylingual and polycultural poet, one of the "Lighthouse keepers" of modern literature as the heroes of her essay millenials, children with "older hearts".

Key words: Millenials, Poetry, Childhood

\section{GENERATION "Z"}

For the majority of people childhood semantics is homogeneous: the warmth of mother's hands, Granny's care, the huge world, milk froth, the sweets of friendship, reverential waiting for a miracle, Santa Claus, or waiting for daddy from his job. We interviewed a number of people, what they associate with the phrase "the poems about childhood and children". The answers were as follows: dedication of the mother to her child; text about children's joys and sorrows, initially of recognition, novelty of just opened the world; easy for reading and memorizing poems on behalf of a kid, who is just starting to get acquainted with the world of letters, sounds and words, couplets, the good fairy tales. As to millennials, they write about childhood in dark shades.

Let's define who we mean by millennials. It is people born in the late 80's and early 90's. Most of them already have several published books or, at least, public, numbering from a few dozen to a few hundred thousand subscribers. The variety of definitions of the word "poet" is widely discussed both in the style of Kitchen Philosophy and in TED sensational stand up lectures. The discourse of modern network literature offers a wide variation of the interpretation of the symbolism of the already established images. We will not discuss texts about happy childhood and fairy tales for children - they merit a separate article. This research is an analytical slice of non-standard, complex, and heavy images of childhood and child himself. It is done through the prism of poems, and their authors are of our time.

\section{SHAPES OF THE MIRROR}

Here they are, in atypical genres of Millenials' poetry. 


\section{Letters-prolepsises to unborn children}

The term "children's children" was first used in the 60's regarding the Hippie movement. It includes both the typical symbols of child (laughter, crying with no reason, infinite energy, lack of fear, "no" to war and violence, and openness to the world) and tininess towards the world and inadaptability to life. The text of the poetess Springteen refers, in fact, to the hippies' grandchildren. What can a parent, who is in the dark of how to live a life, teach his child? And what will the grandchild learn? To what will this "infantilism chain", where all the links are weak, lead? In a poem, addressed to a lyric heroine's potential daughter, the author raises a sharp social problem of human weakness when it comes to its social role as a parent. The text was repeatedly published on variety of child-free forums and gained whole-hearted support among their inhabitants (childfree are people who consciously choose not to have children. - Author's note). The semantic field of childhood from this author is a cold winter field: "blank incurious stare" (lack of trust between mother and daughter), "foisted patronymic" (you can include any person the passport column "father"). The childhood becomes endless and lingering like a disease for many children: hence the metaphor "The Epidemic of Infantilism". Lyrical heroine is afraid to give birth and then make changes to a sophisticated "program" called "Human", because she is already "programmed" as of no account.

Ты не создана, а о тебе уже говорят. Выбирают едва ли не университет. Открывают проект, закладывают заряд, и отводят сухие ладони семи смертей. Мне заведомо страшно за твой безразличный взгляд. Мне заведомо больно за пение в пустоте.

Ибо дети детей однажды продолжат ряд и появятся снова дети детей детей. Запрещу тебе петь: это значит, ты будешь петь. Разрешу стихи: не захочется ни строки.

Потому что тетрадка в клетку - простая клеть, даже если все это игры в черновики.

Это путь, на который не надо успеть успеть. Это то, от чего, пожалуйста, убеги.

Будь луной и водой, и зря слова не роняй. Ибо тянется солнце к солнцу, огонь к огню.

Я боюсь создавать тебя и потом менять. Мать меня не вернула. А я тебя ли - верну?

Ибо дети детей появятся от меня. И последним не быть - ни одному звену. Эпидемию инфантильности, красных слов, синих глаз, подкидного отчества, тошноты не схватить бы студеным ветром чужих голов, пусть и это, и то, только - не ты, не ты. [1].

Человечий гербарий Бог кладет под стекло: вот сушеные ветки, а вот живые цветы

\section{A child, who is mature beyond his years}

The image of the child, who not only protects his parents, who go soft at a bad time, in hour of need, but also grows up in a moment, becomes more and more popular in the media, and poets pick up the trend. Let's give examples from the world of cinema. An animated film "Mulan" has a young heroine who went to war because her father was disabled. In "Spirited away", Chihiro's parents indulged in sin of gluttony and turned into fat pigs, and the girl is looking for a way to rescue them throughout the film. Text by Viviana Steletskaya focuses the reader's attention to family values: "The children patrol the city. They don't need another world. They might continue to play or run away from the city, but they suddenly adopt the role of an "Adult", while their parents silently adopt the 
role of a "Child". Here, the winter and its attributes are symbols of parental aging and quietus.

Зимы становятся все длиннее, нет им подобных на белом свете.

Взрослые медленно цепенеют, значит, к оружию встанут дети.

$$
<\ldots>
$$

Дети еще не узнали смерти. Смерть - это нечто из мира сказок.

Страхом и паникой правит холод. Стекла дрожат под напором стужи.

Дети обходят дозором город. Мир за пределами им не нужен.

$$
<\ldots>
$$

Если безумия черен омут, если беда расставляет сети,

Если родители впали в кому, значит, на улицы выйдут дети [2]

\section{Severely ill child}

It is the topic of a river of tears, fraud and many poems. In the poetic «clubbish set» you can hear that, having such texts, you will walk everyone over. A poem by Mariana Vysotskaya is mere pain:

У Дениса взрослый диагноз и детский почерк.

Он сильнее ровесников. Благоразумней прочих.

Он пишет в записке «С наступающим, милый Отче!

Я один на один против пары поломанных почек».

Я стою перед ним. Румяная и живая.

Он знает, что не выживают. Живут, уповая.

Я, - говорит, - жду донора, как трамвая.

$<\ldots>$

- С Новым Годом, Бог. С Новым Годом, святые и грешные.

Когда я умру - ты покормишь меня черешнями?

- С Новым Годом, Денис. Покормлю, конечно же [3].

A boy called Denis has an unusually mature thinking. In his world, there is no one to wish Happy New Year: his interlocutor is the God. The others, as a lyrical heroine in his eyes, are saints or sinners. If the pain is real, it's not suitable for contest.

\section{The first and painful discoveries}

The text by the Moscow poetess Alexandra Shalashova can seem a Christmas fairy vignette - at first sight, but just up to the second line.

Маму на ночь обнять, в одеяле хранить тепло...

В нашей кухне свинья окровавила чистый пол, разлеглась как дите - и ладошки ведет ко мне.

Вот кухарка идет приготовить ее в огне.

Говорят, поделом ей лежать и терпеть тесак, а кому мы - добром, а кому - топором в глаза.

Мы не делали зла, мы изладили дом и клеть, добрый бог наказал, что свинье завсегда терпеть. Раз в пещере лежали - и слон, и бизон, и тигр, и сияла Звезда, и горел огонек в пути, но Младенец не спал, и игрался звездой январь, и рыдала свинья, и ревела во всю гортань. 
Как ни грел Его лев и ни нянчил Его буй-тур, но нахохлился хлев, предвешая Ему беду: что себя потерять, не ударив огнем о трут: и теперь нам свинья ненавистнее всех иуд.

Заметает куртины. Иней к земле метет

Бередит скарлатина. Няня несет питье.

Я лежу в рождество в лихорадке запавших скул, а на праздничный стол на тарелке свинью несут.

A lyric heroine - a child - realizes how painful thoughts can be. The text is about nostalgia, which is not always bright and joyful. That even in holidays you have to be sick and think about something complex, unchildish. That children are smarter and think in a more complicated way than their parents and kindergartner thinks about them.

\section{Tough childhood}

What can really harm a child, except a bad company, crisps, and ARVI? Indifference, inattention, domestic violence, parental overexagerrating demands. SimaRadchenko's poem explains how the child was «suddenly» found in the house. In the era of information technology, parents are passionate about gadgets, career development and themselves, but when the lights are turned off, a spiritual image emerges - candles, a symbol of the divine, showing a little man from the darkness. And it turns out that this little man knows a lot. In the morning, everything seems to be as usual:

Внезапновдомеотключилисвет. Нет света - и заняться тоже нечем...
Родители устроили совет. В конце концов нашлись на полке свечи.
$<\ldots>$
И в темноте тягучей и густой вдруг оказалось: в доме есть ребенок.
Он, оказалось, был уже давно, и говорил неплохо, и о многом,
но как-то было все не до него - «уйди и не мешайся, ради бога».
$<\ldots>$
А утром... утром снова дали свет. И снова стал ребенок невидимкой.

\section{«Children over 20»}

Archet, a very popular poet, has 35000 subscribers only in one of the social networks. This is an amazing and rare case when the author's audience is so cohesive they read the text by heart together with poet: "God save the children over 20. They still have to die and fall out". It goes without saying that fans of Archet are called as "Children over 20". After that, some resonant verses appeared: "God save the children over 18", "over 40", etc. The heroes of these poems are marginal, strange individuals, going against the rules. They overgrew the puberty but continued to keep a spark of rebellion inside. Those people are of alternative orientation. They have not a healthy lifestyle to lead, nevertheless, they are children, because the God is the one.

\section{Childhood "from scratch"}

A little human begins to remember himself and the world when he is two or three years old. The poem by Ira Znamenosets is about how a lyrical heroine remembers herself at the very birth, as well as her parents, who get divorced when heroine becomes older. 


\section{Я запомнила это. Вздохнула и завопила. \\ Поднялось беспощадное солнце июльское, ослепило. Навсегда ослепило.}

$$
<\ldots>
$$

То, что я - симбиоз тех двоих, невозможных вместе.

Значит, я - невозможна. Возможностью мир закован.

Значит, я выше мира и выше его законов.

И он будет таким, как запомнился мне в начале,

Тем июлем, когда я рождалась, в крови кричала.

$$
<\ldots>
$$

\section{SUMMING UP}

To sum up, the millennials see the childhood in the poetry from other angles, unlike the generation $X$. It is impossible to come across poems about deliberate child-free among representatives of the postwar period. The childhood is less and less associated with a bright and trouble-free period of human life. The image of the child expands: it's a new "Mitrofanushka - The Minor", and a five-years old brave heroine, and a future undesirable daughter, and an invisible son, and mature thoughts in the child's head. The symbolics of childhood expands the palette of paints and works, in fact, based on the principle of synaesthesia, or molecular cuisine: the text can be named "A Child", but it will be about a man of forty. What will giveus the poetry of generation $\mathrm{Z}$ ?.

(C) Danilova S., 2017

\section{REFERENCES}

[1] Springteen https://vk.com/stefaniadanilova?w=wall-

[2] Steleckaya Viviana: https://vk.com/mela_mela?w=wall-35719059_456

[3] Vysockaya Maryana: https://vk.com/sexondhand?w=wall-51214103_7555

[4] Shalashova Alexandra: https://vk.com/lenty_derevjev?w=wall-118863647_87

[5] Radchenko Sima: https://vk.com/sexondhand?w=wall-51214103_7318

[6] Archet: https://vk.com/sir_archet?w=wall-23568161_99

[7] Znamenosets Ira: https://vk.com/vnychkalenina?w=wall-42145490_3146

\section{Article history:}

Planned: 12.12 .2016

Accepted: 09.01.17

Moderator: Olga Valikova

\section{For citation:}

Danilova S. (2017). Black Mirror: Destroying the Idyll of happy Childhood, or the Socium Today in the Millenials' Poetry. RUDN Journal of Language Education and Translingual Practices, 14 (1), 110-115.

Bio:

Stefania Danilova, Member of the Russian Writers' Union, winner of prestigious literary awards, undergraduate of the St. Petersburg University. E-mail: ichwerdewarten@gmail.com 


\title{
ЧЕРНОЕ ЗЕРКАЛО: РАЗРУШЕННАЯ ИДИЛЛИЯ СЧАСТЛИВОГО ДЕТСТВА, ИЛИ ОБЩЕСТВО СЕГОДНЯ В ПОЭЗИИ МИЛЛЕНИАЛОВ
}

\author{
Стефания Данилова \\ Санкт-Петербургский государственный университет \\ Университетская наб., 7-9, Санкт-Петербург, Россия, 199034
}

Это эссе - попытка заглянуть в «черное зеркало» утраченных - или инверсированных социальных мифов. Оно о сообществе разобщенных людей; о новом поколении креативных личностей - миллениалов - которые пытаются найти свое место в мире разными способами, и главный из них - Поэзия.

Стефания Данилова - самый молодой член Союза писателей России. Это транслингвальный и поликультурный поэт, «Смотритель маяка» современной литературы наряду с героями ее эссе - миллениалами, детьми со «взрослыми сердцами».

Ключевые слова: миллениалы, поэзия, детство

\section{СПИСОК ЛИТЕРАТУРЫ}

[1] Springteen https://vk.com/stefaniadanilova?w=wall-33426079_47524

[2] Стелецкая Вивиана https://vk.com/mela_mela?w=wall-35719059_456

[3] Высоцкая Марьяна https://vk.com/sexondhand?w=wall-51214103_7555

[4] Шалашова Александра https://vk.com/lenty_derevjev?w=wall-118863647_87

[5] Радченко Сима https://vk.com/sexondhand?w=wall-51214103_7318

[6] Арчет https://vk.com/sir_archet?w=wall-23568161_99

[7] Знаменосец Ира https://vk.com/vnychkalenina?w=wall-42145490_3146

\section{Для цитирования:}

Данилова С. Черное зеркало: разрушенная идиллия счастливого детства, или общество сегодня в поэзии миллениалов // Вестник Российского университета дружбы народов. Серия: Вопросы образования: языки и специальность. 2017. Т. 14. № 1. С. 110-115.

Об авторе:

Стефания Данилова, член Союза писателей Российской Федерации, лауреат престижных литературных премий, магистрант Санкт-Петербургского университета. Е-mail: ichwerdewarten@gmail.com 